\section{Regards sur l'économie allemande}

Bulletin économique du CIRAC

$107 \mid 2012$

Varia

\title{
Conventions collectives
}

STOLLE B., Die Flexibilisierung des Tarifrechts in Deutschland und in Frankreich

\section{OpenEdition}

\section{Journals}

Édition électronique

URL : http://journals.openedition.org/rea/4505

DOI : $10.4000 /$ rea. 4505

ISBN : 978-2-8218-1424-0

ISSN : 1965-0787

Éditeur

CIRAC

Édition imprimée

Date de publication : 20 décembre 2012

ISSN : 1156-8992

Référence électronique

"Conventions collectives », Regards sur l'économie allemande [En ligne], 107 | décembre 2012, mis en ligne le 14 janvier 2013, consulté le 22 septembre 2020. URL : http://journals.openedition.org/rea/ 4505 ; DOl : https://doi.org/10.4000/rea.4505

Ce document a été généré automatiquement le 22 septembre 2020

(C) CIRAC 


\section{Conventions collectives}

STOLLE B., Die Flexibilisierung des Tarifrechts in Deutschland und in Frankreich

\section{RÉFÉRENCE}

STOLLE B., Die Flexibilisierung des Tarifrechts in Deutschland und in Frankreich, Coll. Mannheimer Schriften zum Unternehmensrecht, vol. 23, Nomos, Baden-Baden, 2011,280 p.

1 Les mutations intervenues ces dernières décennies ont généré, en France comme en Allemagne, une demande de flexibilité accrue dans le fonctionnement du partenariat social. Dès lors, des solutions individuelles doivent pouvoir être proposées à l'échelle de chaque entreprise, l'enjeu étant de conserver dans le même temps une certaine sécurité en matière de planification et d'assurer la paix juridique. Tandis qu'en Allemagne, cette mission revient aux partenaires sociaux, en France, c'est au législateur d'agir. Un premier pas a été franchi avec la loi de 2004 venant assouplir la hiérarchisation des niveaux de négociation. Cette loi a servi de point de départ à cette thèse de doctorat portant sur la comparaison franco-allemande de la législation en matière de conventions collectives. (sh) 